\title{
SISTEM PENGURASAN UNTUK PEMBERSIHAN PIPA FLUIDISASI
}

\author{
(Sebagai Perawatan Pipa Fluidisasi Untuk Pemeliharaan Alur Muara Sungai)
}

\author{
Hendrik Pristianto'), M. Arsyad Thaha2), Mukhsan P. Hatta'), dan Mary Selintung() \\ 1) Dosen Jurusan Teknik Sipil Universitas Muhammadiyah Sorong, Papua Barat \\ 2),33,4) Dosen Jurusan Teknik Sipil Universitas Hasanuddin Makassar, Sulsel \\ Email : tekniksipilsorong@gmail.com
}

\begin{abstract}
Abstrak
Metode fluidisasi sebagai teknik baru pemeliharaan alur muara sungai yang sudah dikaji di Indonesia melalui rangkaian penelitian skala laboratorium. Salah satu permasalahan yang menyertai penerapan metode fluidisasi adalah penyumbatan pada lubang perforasi dan penyumbatan pipa fluidisasi akibat masuknya sedimen. Penelitian ini bertujuan untuk mengkaji pengaruh variasi ketinggian sedimen dalam pipa fluidisasi terhadap tekanan dan waktu yang dibutuhkan untuk penggelontoran sedimen keluar dari dalam pipa fluidisasi. Penelitian ini berdasarkan percobaan model fisik di laboratorium dengan menggunakan sampel sedimen berupa 3 sampel pasir pantai dari 3 muara Sungai Jeneberang, muara Sungai Panoang dan muara Sungai Bialo. Variasi terdiri dari debit pengurasan, tinggi sedimen dalam pipa, tinggi sedimen di luar pipa, dan berat jenis pasir. Hasil penelitian memperlihatkan bahwa semakin kecil kecepatan aliran dan semakin tingginya sedimen dalam pipa akan menurunkan nilai rerata gradien tekanan pada pipa horizontal, sedangkan pada pipa vertikal terjadi peningkatan nilai rerata gradien tekanannya. Sedangkan waktu pengurasan akan semakin singkat seiring dengan meningkatnya koefisien kecepatan alirannya.

Kata kunci: sedimen dalam pipa fluidisasi, tekanan penggelontoran.
\end{abstract}

\section{Abstract}

Fluidization method as a new river channel maintenance technique have been studied in Indonesia on laboratory scale research series. One of the problems rise by utilizing this method is perforation holes clogging due to to the sediment. This study aimed to investigate the effect altitude variation of sediment in the pipe toward pressure and time required to flush the sediment from the pipe. The research is based on laboratory models using three sediment samples that was from Jeneberang, Panoang and Bialo Estuary. Variatio consists of flushing flows, sediment height inside and outside the pipe, and sediment density. The study shows that the lower the flushing velocity and the highest sediment inside the pipe to decrease the pressure gradient value on the horizontal pipe, while on the vertical pipe to increase the pressure gradient value. While flushing time decrease along with velocity coefficient increase.

Keyword : fluidized sediment, flushing pressure.

\section{PENDAHULUAN}

\section{Latar Belakang}

Pada bidang teknik pantai, metode fluidisasi mulai didorong untuk dikembangkan sebagai suatu alternatif penanganan masalah sedimentasi baik pada alur pelabuhan, saluran navigasi ataupun perawatan muara. Disebutkan bahwa Weisman and Lennon pada tahun 1994 melaporkan adanya serangkaian hasil penelitian fluidisasi secara eksperimental dan analitis telah dilakukan di Amerika Serikat sejak tahun 1977. Rangkaian penelitian tersebut meliputi desain pipa fluidisasi, ukuran dan spasi lubang perforasi, serta debit dan tekanan yang dibutuhkan untuk fluidisasi.

\section{Permasalahan}

Salah satu permasalahan yang menyertai penerapan metode fluidisasi adalah penyumbatan pada lubang perforasi dan penyumbatan pipa 
fluidisasi akibat masuknya sedimen. Dari penelitian terdahulu didapat beberapa rekomendasi, yaitu :

- Pentingnya penelitian dan kajian tentang sistem flushing (pengurasan) sebagai perawatan pipa fluidisasi (Darmawan, 2004).

- Penelitian lanjutan termasuk sistem pembersihan pipa, desain saringan pipa inlet dan proyek percontohan perlu diadakan untuk menguji kinerja teknologi ini (Thaha, 2006).

- Perlunya penelitian lanjutan dengan meninjau pengaruh variasi-variasi lainnya seperti : berat jenis dan konsentasi sedimen, kemiringan pipa fluidisasi, tinggi dan sudut pipa, serta tekanan yang diperlukan untuk flushing (Musriati, 2009).

\section{Ruang Lingkup}

Ruang lingkup penelitian ini adalah kajian model fisik di laboratorium untuk meneliti sejauh mana pengaruh variasi ketinggian sedimen dalam pipa fluidisasi terhadap waktu pengurasan dan tekanan yang dibutuhkan oleh sistem pengurasan untuk pembersihan pipa fluidisasi .

\section{Tujuan dan Sasaran}

Tujuan penelitian ini adalah untuk meneliti pengaruh variasi ketinggian sedimen dalam pipa terhadap :

a. tekanan yang dibutuhkan untuk membersihkan sedimen pada pipa horisontal dan pipa vertikal.

b. waktu yang dibutuhkan untuk penggelontoran sedimen keluar dari dalam pipa fluidisasi.

Adapun sasaran dari penelitian ini adalah :

a. Sebagai alternatif solusi untuk memecahkan masalah penyumbatan pada pipa fluidisasi.

b. Sebagai pengembangan penelitian tentang transport sedimen pada pipa horisontal, dan pipa vertikal.

\section{TINJAUAN PUSTAKA}

1. Metode Fluidisasi

Thaha (2006) melakukan penelitian mengenai perencanaan teknis metode fluidisasi. Dari penelitian ini diketahui dua faktor penting yang berpengaruh yaitu tenaga air (energi head) yang dibutuhkan untuk mengangkut sedimen dan dimensi alur optimal yang dapat dihasilkan (geometric elements).

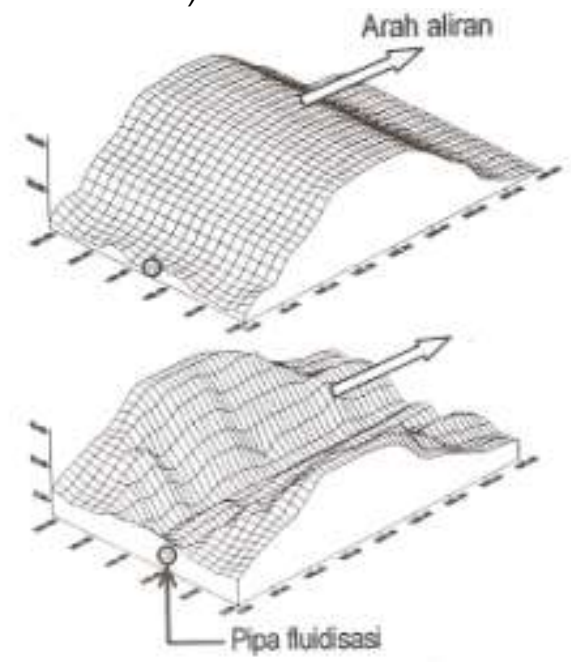

Gambar 1. Ilustrasi geometrik alur sebelum dan sesudah fluidisasi (Thaha, 2009)

\section{Masalah Clogging Pada Pipa FLuidisasi}

Permasalahan penyumbatan pipa fluidisasi akibat masuknya sedimen melalaui lubang perforasi diteliti oleh Dharmawan (2004), Taufik dan Triyanto . Penelitian ini menghasilkan variasi model tipe 3 mampu menghambat sedimen yang masuk ke dalam lubang berforasi $60 \%$ dari pada tipe lubana WL dan membuat alur lebih dalam.
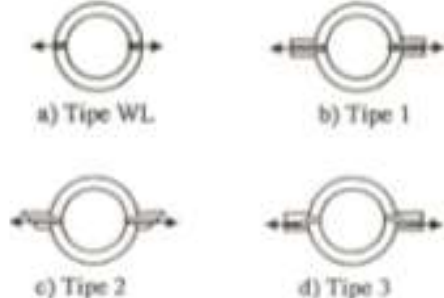

Gambar 2. Empat tipe lubang yang dikaji oleh Weisman-Lennon (a), Taufik (b), Darmawan (c) dan Triyanto (d) (Thaha, 2006) 


\section{Sistem Pengurasan Pipa Fluidisasi}

Musriati (2009), membuat 4 model sistem pengurasan yang pengujiannya dilakukan dengan variasi volume sedimen dan variasi waktu. Beberapa hal yang menjadi hasil penelitiannya adalah sistem Flushing bisa bekerja secara efektif pada konsentrasi maksimal sedimen kurang dari 0,5 volume pipa fluidisasi, dan pipa fluidisasi dengan lubang perforasi tipe WL lebih mudah dalam memflushing, tapi sedimen dari luar juga lebih mudah masuk.

\section{Prinsip Dasar Metode Fluidisasi}

Prinsip dasar metode fluidisasi adalah terjadinya keseimbangan antara gaya ke atas zat cair dengan berat butiran sedimen yang berada di dalam cairan. Setelah berat butiran sedimen terdukung oleh gaya ke atas, maka zat cair dan sedimen akan menjadi sama dan tak terputus dalam aliran dengan kondisi tetap (Thaha, 2006). Proses fluidisasi menurut Weisman dan Lennon dapat dilihat pada gambar 3.

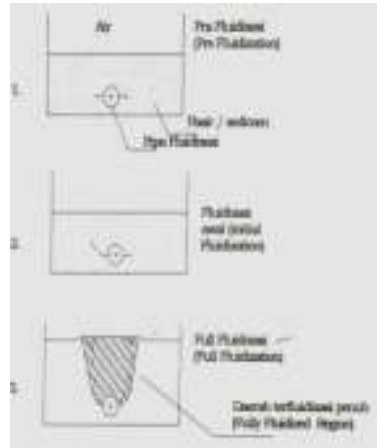

Gambar 3. Tahapan fluidisasi menurut WeismanLennon (Thaha, 2006)

\section{Masuknya Sedimen Ke Dalam Pipa Fluidiasi}

Penyebab utama masuknya sedimen ke dalam pipa fluidisasi, adalah karena masuknya melalui lubang perforasi dan melalui aliran dari pompa fluidisasi

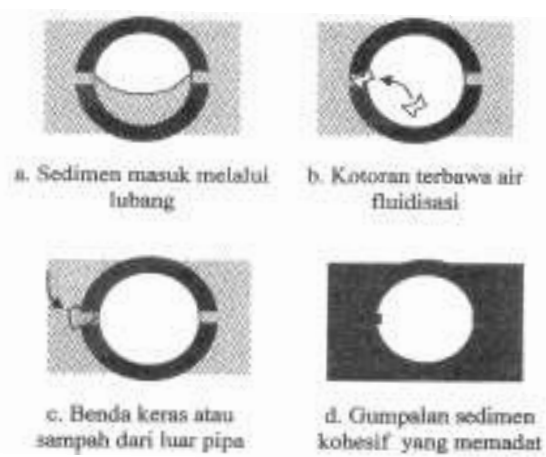

Gambar 4. Skema penyebab tersumbatnya lubang perforasi (Thaha, 2006)

\section{Teori Transpor Sedimen Dalam Pipa}

Menurut Nayyar (2000), terdapat empat regime aliran sedimen dalam pipa, yaitu : Homogeneous Flow, Heterogeneous Flow, Intermediate Regime, Saltation Regime. (deskripsi dapat dilihat pada gambar 5, 6 dan 7)

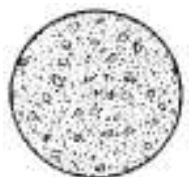

(a)

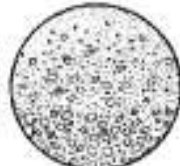

(b)

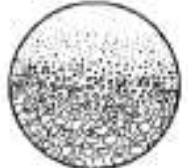

(c)
Gambar 5. Aliran Sedimen Dalam Pipa, a. Homogen, b. Heterogen, c. Saltation (Kuhail, 2001)

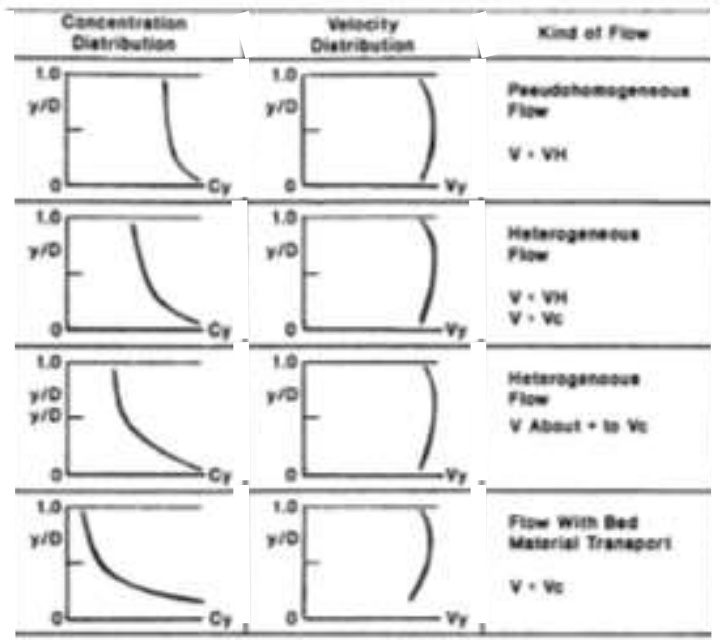

Gambar 6. Skema konsentrasi sedimen dan distribusi kecepatan dalam pipa (Herbich, 2000) 


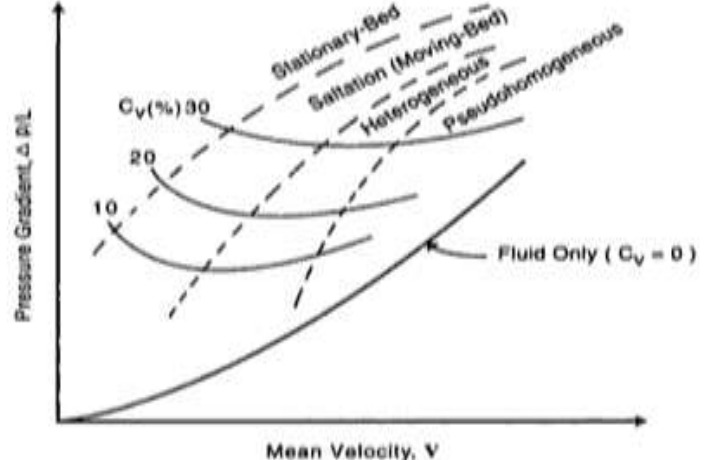

Gambar 7. Variasi gradien tekanan terhadap rerata kecepatan aliran pada konsentrasi sedimen yang berbeda (Liu, 2003)

Pada tahun 1971, Wasp dkk mengajukan persamaan dibawah ini untuk mengklasifikasikan aliran slurry:

$\log \frac{C_{T}}{C_{A}}=1.8 \frac{V_{S}}{\kappa U_{*}}$

dimana $\log =$ logaritma biasa (berbasis -10$) ; \quad C_{A}$ dan $C_{T}=$ konsentrasi volume dari sedimen pada titik axis pipa (garis tengah), dan titik atas pipa pada lokasi $0,92 \mathrm{D}$ dari dasar pipa $V_{s}=$ settling velocity ; $\mathbf{k}$ $=$ konstanta von Karman (untuk aliran slurry $\leq 0,4$ ) ; $U_{*}=$ shear velocity, yang didapat sesuai dari persamaan (2) yaitu :

$U_{*}=\sqrt{\frac{\tau_{o}}{\rho}}=V \sqrt{\frac{f}{8}}$

Persamaan (1) dan (2) dapat digunakan untuk menghitung rasio konsentrasi $C_{T} / C_{A}$, dan hasilnya dapat digunakan untuk mengklasifikasi aliran sedimen dalam pipa yaitu Pseudohomogeneous , jika $C_{T} / C_{A}>0,8$; Heterogeneous, jika $C_{T} / C_{A}<0,1$; dan Intermediate, jika $0,8>C_{T} / C_{A}>0,1$

\section{Regim Aliran Homogen}

Untuk aliran psudohomogeneous bahwa mempunyai rasio konstan antara shear, $T$ dan gradient kecepatan, $d u / d y$. Gradien tekanan dalam kasus ini dapat dikalkulasikan dari :
$i_{m}=\frac{\Delta P_{m}}{L}=f_{m} \frac{1}{D} \frac{\rho_{m} V^{2}}{2}$

\section{Regim Aliran Heterogen}

Ketika sedimen dalam pipa secara total tersuspensi oleh mengalirnya air (dengan kata lain yaitu ketika alirannya heterogen), kehilangan tenaga akibat gesekan dari aliran sepanjang pipa dapat dihitung dari modifikasi persamaan Durand:

$\Phi=\frac{i_{m}-i}{i C_{v}}=67\left(\frac{\sqrt{g D(S-1)}}{V}\right)^{3}\left(\frac{V_{S}}{\sqrt{g(S-1) d_{s}}}\right)$

dimana $\Phi$ adalah fungsi dimensi; $i_{m}$ adalah gradien tekanan dari aliran campuran (slurry) , yakni, $i_{m}=\Delta p_{m} / L ; i$ adalah gradien tekanan aliran zat cair (air) dalam pipa yang sama pada kecepatan yang sama $V$ yakni $I=\Delta p / L$.

Sebagai pembanding dari persamaan (4), maka Nayyar (2000) menyampaikan suatu formula untuk menghitung besarnya friction loss untuk regim aliran heterogen dalam pipa dan diajukan oleh Durand :

$\frac{i-i_{w}}{C_{V} i_{w}}=81\left[\frac{V^{2} \sqrt{C_{D}}}{(s-1) g D}\right]^{-1.5}$

dimana $: \mathrm{i}=$ friction loss untuk slurry, $\mathrm{ft}(\mathrm{m})$ air per $\mathrm{ft}(\mathrm{m}), i_{w}=$ friction loss untuk air, $\mathrm{ft}(\mathrm{m})$ air per $\mathrm{ft}$ (m) pada kecepatan yang sama, $C_{D}=d r a g$ coefficient dari partikel zat padat yang tersuspensi mengendap dalam fluida yang luasnya tidak terbatas, $s=$ specific gravity dari partikel zat padat.

\section{$\underline{\text { Regim Aliran Intermediate }}$}

Untuk memprediksi gradien kecepatan dari regime aliran intermediate, dipakai rumus yang telah dikembangkan oleh Fei di Cina, yaitu :

$$
\begin{aligned}
i_{m h} & =\frac{i_{m}}{\rho g}=\frac{\Delta P_{m}}{\rho g L} \\
& =\alpha \frac{f V^{2} S_{m}}{2 g D}+11 \eta_{s} C_{v}\left(S-S_{m}\right) \frac{V_{s a}}{V}
\end{aligned}
$$


dimana $i_{m h}$ adalah gradien headloss dalam $\mathrm{m} / \mathrm{m} ; V$ adalah kecepatan rerata dalam pipa; $S_{m}$ adalah berat jenis campuran dibagi dengan berat jenis zat cair (air); $S$ adalah berat jenis sedimen dibagi dengan berat jenis zat cair; $C_{v}$ adalah konsentrasi volume sedimen dalam slurry; dan $V_{s a}$ adalah kecepatan rerata pengendapan sedimen.

\section{Regim Aliran Sedimen Pada Pipa Vertikal}

Total head pada pipa vertikal dinyatakan dalam bentuk (diasumsikan dalam tinggi air) adalah (Stephenson, 1976) :

$H_{m}=H\left(1+i_{w}\left(\frac{V_{w}}{V}\right)^{2}+q(s-1)\right)$

dimana $\mathrm{H}$ adalah tinggi angkat, $\mathrm{i}_{\mathrm{w}}$ adalah gradient head loss untuk air pada kecepatan aliran V, q adalah konsentrasi spasial dari zat padat berdasarkan volume.

\section{METODOLOGI DAN HIPOTESIS}

1. Metode Penelitian

Penelitian ini dilaksanakan di Laboratorium Hidrolika Fakultas Teknik Universitas Hasanuddin. Metode ini dipandang efektif untuk mengkaji pengaruh variasi ketinggian sedimen terhadap kebutuhan tekanan pada pipa horisontal dan pipa vertikal dalam sistem pengurasan pipa fluidisasi.

Alat-alat yang digunakan antara lain adalah bak air , 2 buah pompa, tabung pitot, manometer, pintu ukur Thompson dan stopwatch

Bahan penelitian terdiri dari pasir yang diuji diambil dari 3 lokasi yaitu Muara Sungai JeneberangMakassar, Muara Sungai Panoang-Bantaeng, dan Muara Sungai Bialo-Bulukumba; pipa PVC 2" dari bahan akrelik dan jaringan pipa suplai dan pipa pembuang

\section{Asumsi Dasar}

Kondisi batas dari penelitian ini :

a. diameter pipa fluidisasi $(D)=0,0508 \mathrm{~m}$, diameter lubang perforasi $\left(D_{f}\right)=3 \mathrm{~mm}=0,003$ $\mathrm{m}$, jarak lubang perforasi $(\mathrm{a})=0,05 \mathrm{~m}$.

b. ketinggian sedimen di dalam pipa fluidisasi $\left(h_{s}\right.$, meter) : $\left[h_{s} / D=0,5 ; 0,75\right.$ dan 0,90$]$

c. ketinggian sedimen di luar pipa fluidisasi $\left(\mathrm{d}_{\mathrm{s}}\right.$, meter) : $\left[d_{s} / D=0 ; 1\right.$ dan 2]

d. panjang pipa horisontal $(\mathrm{L}$, meter $)=2 \mathrm{~m}$, tinggi pipa vertikal $\left(H_{p}\right.$, meter $)=1,2 \mathrm{~m}$, sehingga didapat : $D_{f} / a=0,06$, dan $H_{p} / L=0,6$.

Dalam penelitian ini disusun 3 hipotesis untuk menjawab tujuan penelitian, yaitu :

a. Kebutuhan tekanan untuk mentranspor sedimen dalam pipa horizontal sepanjang $L$ :

$$
i_{H}=f\left(V_{D}, V\right)
$$

$$
\frac{H_{1}-H_{2}}{L}=f\left(V_{D}, V\right)
$$

b. Kebutuhan tekanan untuk menguras sedimen keluar dari pipa flushing setinggi $\mathrm{H}_{\mathrm{p}}$ meter :

$$
\begin{gathered}
i_{V}=f\left(V_{D}, V_{w}\right) \\
\frac{H_{2}-H_{p}}{H_{p}}=f\left(V_{D}, V_{w}\right)
\end{gathered}
$$

C. Waktu atau durasi (t) yang dibutuhkan untuk menguras sedimen keluar dari dalam pipa :

$$
t=f\left(V s, V_{D}, V_{w}\right)
$$

dimana $\mathrm{H}_{1}=$ tinggi tekan hulu (meter), $\mathrm{H}_{2}=$ tinggi tekan hilir (meter), $\mathrm{t}=$ waktu pengurasan (dtk), $V=k e c e p a t a n$ aliran pipa horizontal ( $\mathrm{m} / \mathrm{dtk}), \mathrm{V}_{\mathrm{w}}=$ kecepatan aliran pipa vertikal (m/dtk), kecepatan endap sedimen $\left(V_{D}, m / d t k\right)$ dan $V s=v o l u m e$ sedimen .

\section{Proses Pengumpulan Data}

Untuk memudahkan pengelompokan data penelitian, rancangan simulasi di atas dibagi 
menjadi 3 model, yaitu model A : di luar pipa fluidisasi tidak diisi dengan sedimen, model $B$ : diluar pipa fluidisasi diisi dengan sedimen setinggi $(d s / D)=$ 1, dan model $C$ : diluar pipa fluidisasi diisi dengan sedimen setinggi $(d s / D)=2$.

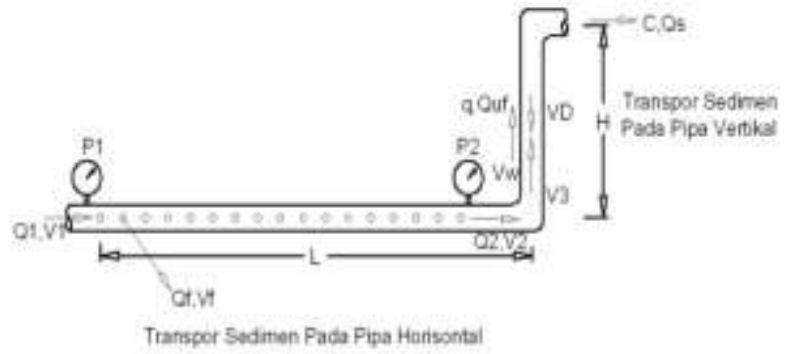

Gambar 8. Ilustrasi Peralatan Penelitian

\section{HASIL KEGIATAN}

Dari kegiatan di laboratorium didapatkan data-data sebagai berikut :

1. Data sedimen, didapatkan bahwa ketiga sampel sedimen dari 3 muara sungai tersebut mempunyai jenis yang sama yaitu pasir sedang, hanya berat jenisnya yang berbeda.

2. Data penelitian flushing pada pipe fluidisasi, yaitu tekanan di hulu (P1), tekanan di hilir (P2), dan Waktu Pengurasan $(\mathrm{t})$

\section{PEMBAHASAN}

1. Klasifikasi Regim Aliran Sedimen

Klasifikasi regim aliran sedimen dari penelitian ini seperti tersaji pada gambar 13, 14, dan 15.

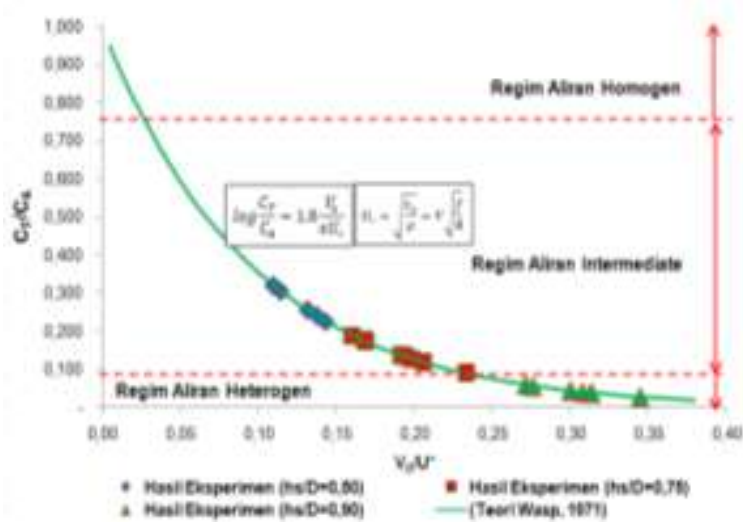

Gambar 9. Klasifikasi Regim Aliran Model A

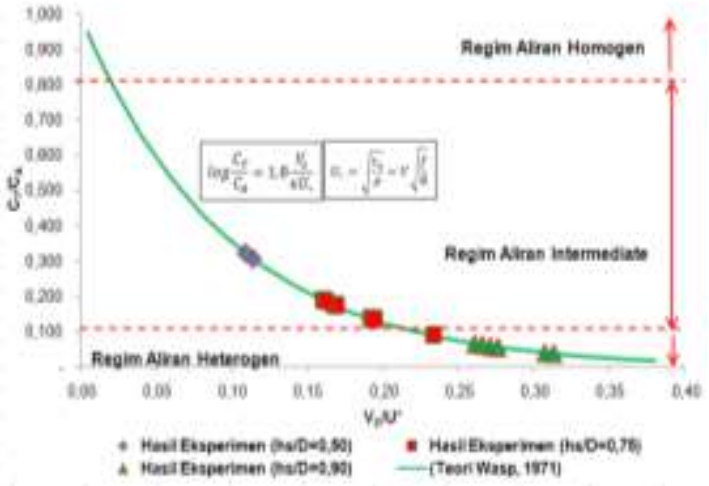

Gambar 10. Klasifikasi Regim Aliran Model B

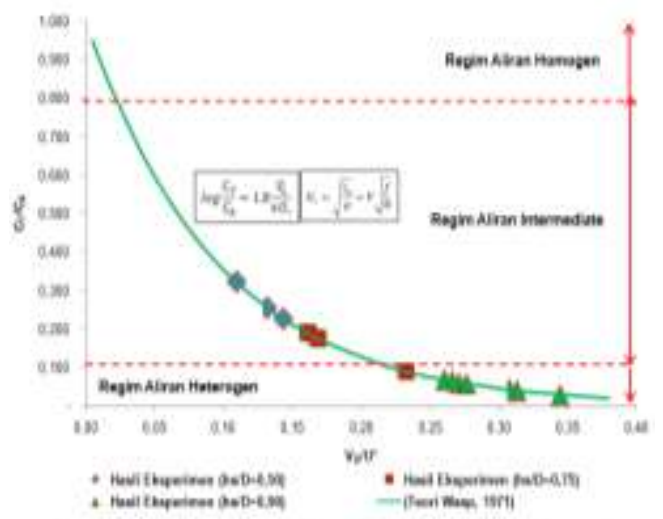

Gambar 11. Klasifikasi Regim Aliran Model C

2. Pengaruh Ketinggian Sedimen dalam Pipa Terhadap :

a. Kebutuhan Tekanan Penggelontoran Pada Pipa Horisontal

Untuk membahas kebutuhan tekanan dalam transport sedimen dalam pipa horisontal, dipakai persamaan (8). Hasil analisa dapat dilihat pada gambar 12, 13 dan 14 di bawah ini.

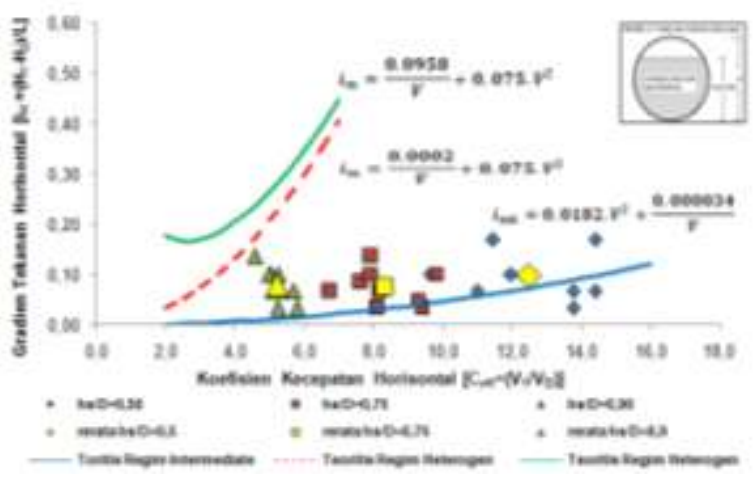

Gambar 12. Hubungan $C_{v H}$ terhadap $i_{H}$ pada Model $A$ untuk $D_{f} / a=0,06$ dan $H_{p} / L=0,6$ 


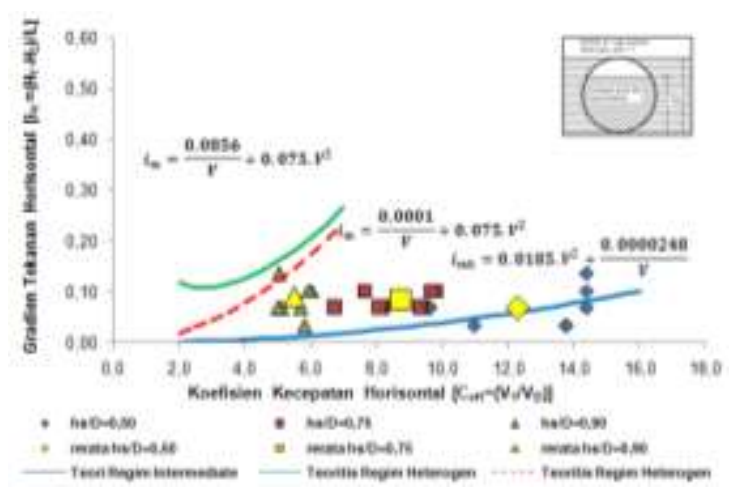

Gambar 13. Hubungan $\mathrm{C}_{\mathrm{vH}}$ terhadap $\mathrm{i}_{\mathrm{H}}$ pada Model B untuk $D_{f} / a=0,06$ dan $H_{p} / L=0,6$

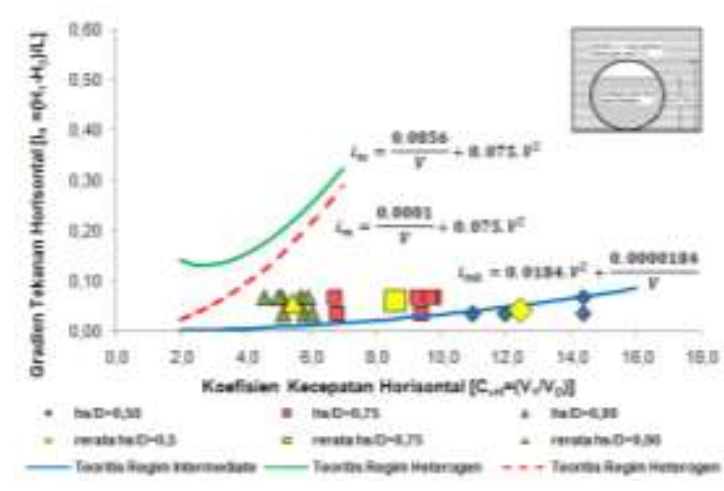

Gambar 14. Hubungan $\mathrm{C}_{\mathrm{VH}}$ terhadap $\mathrm{i}_{\mathrm{H}}$ pada Model C untuk $D_{f} / a=0,06$ dan $H_{p} / L=0,6$

b. Kebutuhan Tekanan Penggelontoran Pada Pipa Vertikal

Untuk membahas kebutuhan tekanan dalam pipa horisontal, dipakai persamaan (9) .

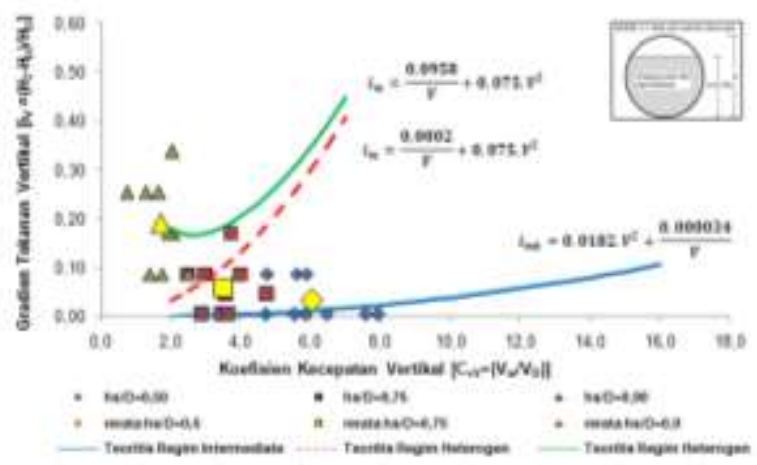

Gambar 15. Hubungan $\mathrm{C}_{\mathrm{v} v}$ terhadap iv pada Model A untuk $D_{f} / a=0,06$ dan $H_{p} / L=0,6$

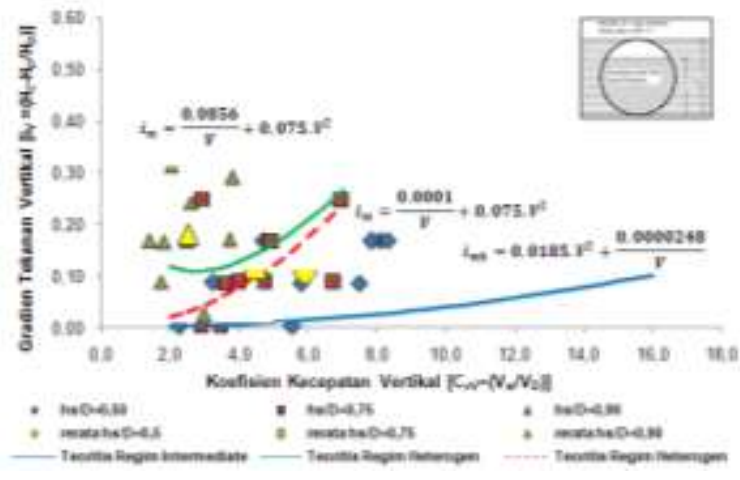

Gambar 16. Hubungan $C_{v v}$ terhadap iv pada Model $B$ untuk $D_{f} / a=0,06$ dan $H_{p} / L=0,6$

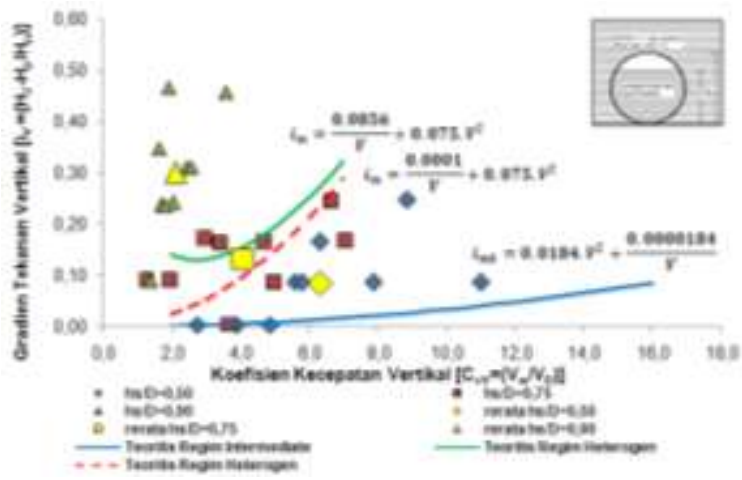

Gambar 17. Hubungan $C_{v v}$ terhadap iv pada Model $C$ untuk $D_{f} / a=0,06$ dan $H_{p} / L=0,6$

c. Waktu Pengurasan

Waktu pengurasan (t) merupakan fungsi dari volume sedimen dalam pipa $(\mathrm{Vs}), \mathrm{V}_{\mathrm{w}}$, dan $V_{D}$. Atau seperti tertulis dalam persamaan (10).

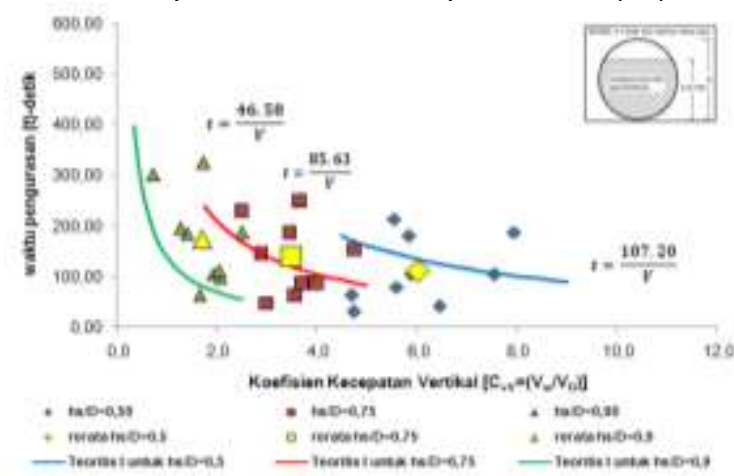

Gambar 18. Hubungan $\mathrm{C}_{\mathrm{v} v}$ terhadap t pada Model A untuk $D_{f} / a=0,06$ dan $H_{p} / L=0,6$ 


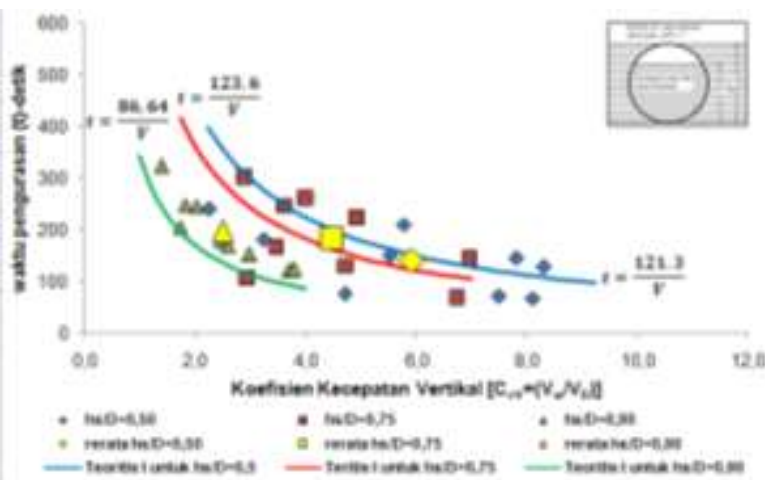

Gambar 19. Hubungan $C_{v v}$ terhadap t pada Model B untuk $D_{f} / a=0,06$ dan $H_{p} / L=0,6$

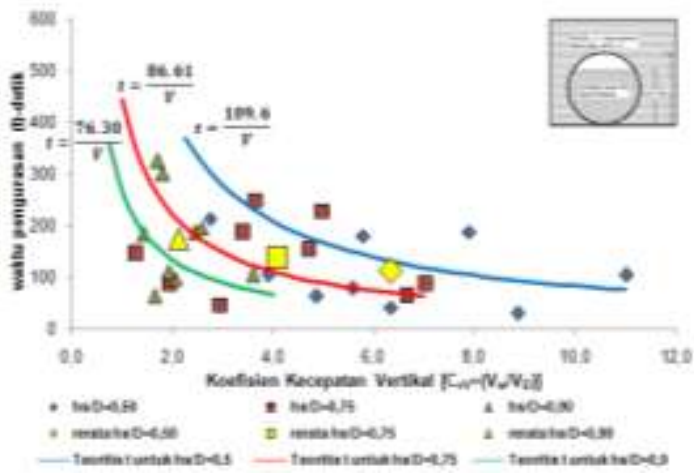

Gambar 19. Hubungan $\mathrm{C}_{\mathrm{vv}}$ terhadap t pada Model $\mathrm{C}$ untuk $D_{\mathrm{f}} / \mathrm{a}=0,06$ dan $\mathrm{H}_{\mathrm{p}} / \mathrm{L}=0,6$

\section{PENUTUP}

\section{Kesimpulan}

Dari hasil penelitian ini dapat dihasilkan beberapa kesimpulan yaitu pengaruh ketinggian sedimen dalam pipa terhadap :

a. kebutuhan tekanan untuk membersihkan sedimen adalah semakin kecil kecepatan aliran dan semakin tingginya sedimen dalam pipa menurunkan nilai rerata gradien tekanan pada pipa horisontal, sedangkan pada pipa vertikal terjadi peningkatan nilai rerata gradien tekanannya.

b. terhadap waktu pengurasan sedimen dalam pipa fluidisasi adalah bahwa durasi pengurasan akan semakin singkat apabila koefisien kecepatan flushingnya meningkat. dalam pipa.
2. Saran

Beberapa hal yang kami sarankan adalah :

1. Penelitian ini masih perlu dilanjutkan dengan meninjau variasi ketinggian pipa flushing, jarak lubang perforasi, diameter lubang, dan panjang pipa fluidisasinya.

2. Perlu dilakukan penelitian lanjutan dengan menggunakan pasir halus dan kasar .

\section{PUSTAKA ACUAN}

Chen, R.C. 1994. Analysis of Homogeneous Slurry Pipe Flow. Journal of Marine Science and Technology. Departement of Mechanical and Marine Engineering, National Taiwan Ocean University, Taiwan, Republic of China. Darmawan, SB. 2004. Pengaruh Perubahan Model Lubang Perforasi Tipe Outlet Untuk Meminimalisasi Sedimen Masuk Pada Pipa Fluidisasi. Universitas Gadjah Mada, Yogyakarta.

Herbich, J.B. 2000,. Handbook of Dredging Engineering (Second Edition). McGraw-Hill. New York, United State of America.

Kuhail, Z. 2001. A Optimum Method for Dredging System. An-Najah Univ, J. Res. Vol.15.

Liu, H. 2003. Pipeline Engineering. Lewis Publisher. Florida, United State of America.

Musriati,N. 2009. Flushing Pipa Fluidisasi. Universitas Gadjah Mada, Yogyakarta.

Nayyar, M.L. 2000. Piping Handbook (Seventh Edition). McGraw-Hill. New York, United State of America.

Stephenson, D. 1976,. Pipeline Design for Water Engineer. Advisory Editor V.T. Chow. Development In Water Science 6. Elsevier Scientific Publishing Company. New York, United State of America.

Thaha, M.A. 2006. Sistem Fludisasi Untuk Rekayasa Pemeliharaan Alur. Universitas Gadjah Mada, Yogyakarta.

Thaha, M.A. 2009. Laporan Akhir Program Hibah Kompetitif Penelitian Unggulan Strategis Nasional. Lembaga Penelitian Universitas Hasanuddin, Makassar. 